\title{
The Performance of Service Marketing Mix Towards Decision in Continuing Education at SMK Lugina Rancaekek, District of Bandung, West Java
}

\author{
Mariana Rachmawati, Mohd Haizam Mohd Saudi*, R. Adjeng Mariana, Tezza Adriansyah Anwar \\ Widyatama University, Indonesia \\ *Corresponding author E-mail: haizam@widyatama.ac.id
}

\begin{abstract}
This paper study on the effect of service marketing mix performance consisting of product, price, place, promotion, people, physical evidence, and process to decision in continuing education at SMK Lugina Rancaekek District of Bandung. The method used is quantitative method with descriptive approach. It used primary data and secondary data. This study was conducted in a field of education with population of all students of class X in SMK Lugina Rancaekek. Sample determination technique used is non-probability sampling technique with purposive sampling approach, which become sample in this research is class X student at SMK Lugina Rancaekek, that is 74 people. Data collection technique is done by questionnaire method, interview, observation, and documentation. Based on the results of study, with multiple regression analysis obtained value of 21,733 . While, the correlation coefficient analysis is 0,607 . The amount of influence of service marketing mix performance to decision in continuing education equal to $36,2 \%$ and the rest $63,8 \%$ influenced by other variable not examined in this study. T test results obtained t value arithmetic on product variables 2,516 , price 2,618 , place 2,565 , promotion 1,999, people 2,577, physical evidence 2,066, and process 2,470 bigger than t table that is 1,9966, then Ha accepted and Ho rejected. Thus, it can be concluded that product variables, price, place, promotion, people, physical evidence, and process affect the decision in education in SMK Lugina Rancaekek.
\end{abstract}

Keywords: Service Marketing Mix; Decision; Marketing Mix.

\section{Introduction}

Today, the education sector has become an attractive business area and has experienced intense competition. As it is realized together that education plays an important role in the effort to realize the quality of human resources. At present, people have begun to realize the importance of education for their lives. In response to this, the central government provides a 12-year compulsory education program. The program is called the Universal Intermediate Program (PMU) which contains recommendations for local governments to organize 12-year compulsory education. With the 12-year compulsory education recommendation for the region / city it will certainly make more and more new schools stand up, especially high school. Law No. 20 of 2003 mandates that secondary education in article 18 is a continuation of basic education [1] further explained that secondary education consists of general secondary education and vocational secondary education. Secondary education in the form of Senior High School (SMA), Madrasah Aliyah (MA), Vocational High School (SMK), and Vocational Aliyah Madrasah (MAK), or other equivalent forms. Schools prepared for the industrial world are vocational high schools where vocational schools are currently required to produce graduate output that can be received directly in the industrial world. Vocational High School (SMK) is one of the secondary education levels which aims to prepare graduates to work. Referring to the contents of the National Education System Law Number 20 of 2003 Article 3 concerning the objectives of national education and the explanation of Article 15, which states that vocational education is secondary education that prepares students, especially to work in certain fields.

Education plays an important role in the effort to realize the quality of human resources. Now, people are beginning to realize the importance of education for their lives. With the increase of educational institutions, the more number of schools, especially the vocational secondary level (SMK). This is a phenomenon that the development of education service providers will lead to a very tight competition among education providers.

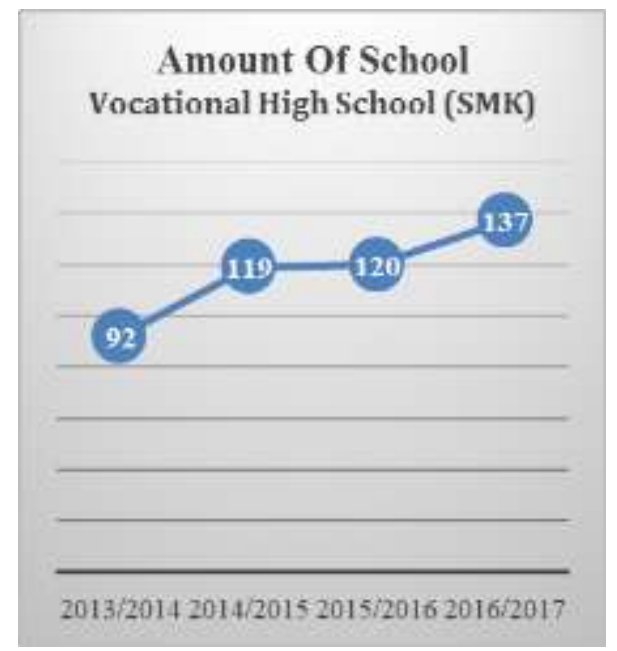

Fig. 1: Amount of Vocational School for Period 2013-2017 


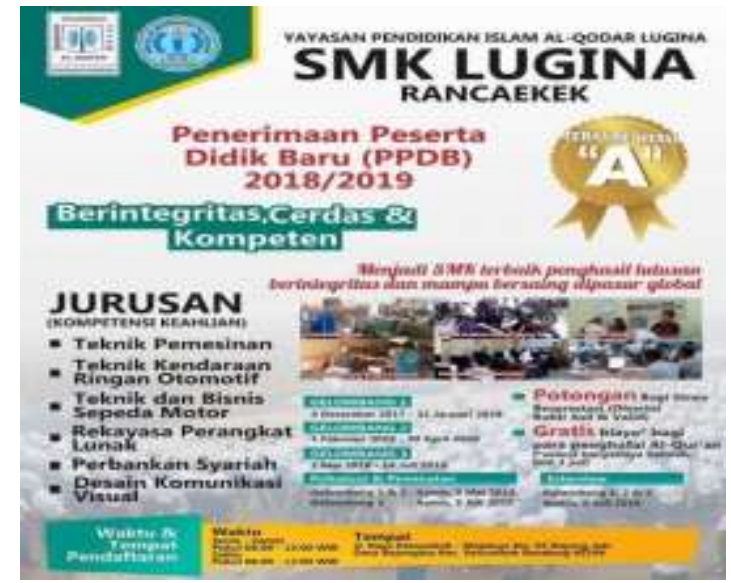

Fig. 2: Advertisement

Table 1: Expertise Program

\begin{tabular}{|c|c|c|c|c|c|}
\hline \multirow[t]{2}{*}{ No. } & \multirow[t]{2}{*}{ Expertise Program } & \multicolumn{4}{|c|}{ Number of Students in Learning Year } \\
\hline & & $2013 / 2014$ & $2014 / 2015$ & $2015 / 2016$ & $2016 / 2017$ \\
\hline 1 & Machining Technique & 72 & 64 & 68 & 59 \\
\hline 2 & Tech. Light Vehicles & 40 & 28 & 45 & 42 \\
\hline 4 & Motorcycle Engineering & 60 & 57 & 65 & 52 \\
\hline 5 & Software Engineering & 65 & 61 & 78 & 83 \\
\hline & Amount Student & 250 & 280 & 302 & 287 \\
\hline
\end{tabular}

With the increasing tight competition, the number of students at SMK Lugina Rancaekek in the last 4 years has decreased. Can be seen in the table beside, in the year 2015/2016 as much as 302 students decreased to 287 students in the year 2016/2017. With the increasing tight competition, the number of students at SMK Lugina Rancaekek in the last 4 years has decreased. Can be seen in the table beside, in the year 2015/2016 as much as 302 students decreased to 287 students in the year 2016/2017. In this case certainly the Lugina Rancaekek Vocational School will try to do a marketing strategy, where the aim is certainly to meet the needs of consumers and satisfy consumers' desires in education better than other competitors. By knowing the desires of consumers to be very important because it can provide an important information to determine the right steps and strategies to influence prospective students to join and retain students who have joined up to study at the vocational secondary level is complete.

The service marketing mix has a strong influence on the success of a marketing mix strategy because the marketing mix strategy has a link to marketing strategy. In understanding the marketing of services in education, the strategy applied is inseparable from the marketing mix strategy. The way to achieve and maintain competitive advantage is through the use of marketing mix elements. Marketing mix in education services is important because consumer decision making is strongly influenced by the marketing mix as well as business in general [4].

According to $[3,8]$ states that education service marketers will offer education services with seven educational marketing tools, also known as 7P namely programs, prices, place (place includes the location and system of service delivery), promotion (promotion), people (people), physical facilities (physical facilities), and process (process). One marketing strategy that can be used by schools is the marketing mix strategy. In [2] define the product as everything that can be offered to meet needs and desires. As for the education sector, in $[5,7]$ revealed that educational service products are the offer of educational services offered by schools which normally include learning activities and other educational services. The product in question is a study program or department that is held on the basis of a curriculum that is intended so that students can master knowledge, attitudes, and behaviors or skills that are in accordance with the goals set.

\section{Framework and Hypothesis}

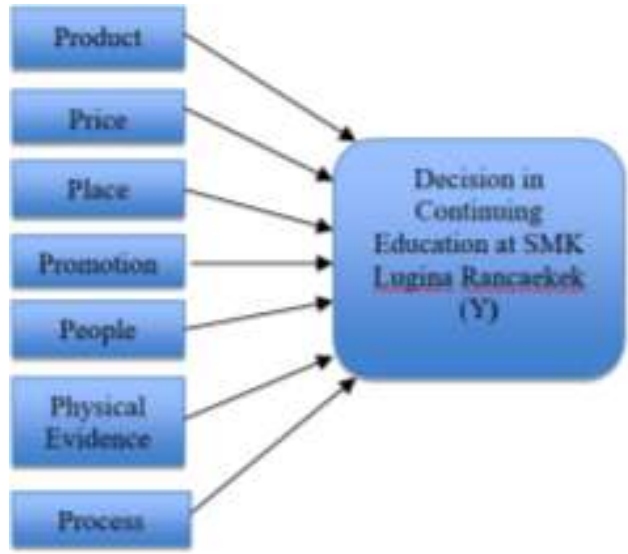

Fig. 3: Research framework

Hypothesis:

1. Product affect the decision in continuing education at SMK Lugina Rancaekek

2. Price affect the decision in continuing education at SMK Lugina Rancaekek

3. Place/Location affect the decision in continuing education at SMK Lugina Rancaekek

4. Promotion affect the decision in continuing education $\mathrm{n}$ at SMK Lugina Rancaekek

5. People affect in the decision in continuing education SMK Lugina Rancaekek

6. Physical Evidence affect in the decision in continuing education at SMK Lugina Rancaekek

7. Process affect the decision in continuing education at SMK Lugina Rancaekek

\section{Methodology}

Object Research Continuing Education at SMK Lugina Rancaekek District of Bandung. Unit Analysis Student 12 District of Bandung. Type of Research: Quantitative methods with descriptive approach. Sampling Technique: Population: Grade X student at SMK Lugina Rancaekek. Sample: 74 respondents 
Sampling Method: Technique of non-probability sampling with purposive sampling. Data Collection Technique: Library research Study Field that is by questionnaires, interview, observation and documentation. Library research. Study Field that is by questionnaires, interview, observation and documentation.
Methods of Analysis: Multiple Regression Analysis. Correlation Coefficient. (Goodness of Fit) Test that is by F test and T test for Hypothesis and Coefficient of determination [9].

\section{Results and Discussion}

Table 2: Goodness of Fit Test

\begin{tabular}{l}
\begin{tabular}{|c|c|c|c|c|c|c|}
\hline \multicolumn{9}{|c|}{ ANOVA $^{\text {a }}$} & F & Sig. \\
\hline \multirow{3}{*}{1} & Model & Sum of Squares & df & Mean Square &, $000^{\text {b }}$ \\
& Regression & 307,900 & 7 & 43,986 & 5,498 & \\
& Residual & 528,060 & 66 & 8,001 & & \\
\cline { 2 - 7 } & Total & 835,959 & 73 & & & \\
\hline
\end{tabular} \\
Dependent Variable: Decision in Continuing \\
b. Predictors: (Constant), Process, Price, Physical Evident, People, Product, Place, Promotion \\
\hline
\end{tabular}

The result shows that $\mathrm{F}$ count $>\mathrm{F}$ table $(5,498>2,15)$, with significant $<\alpha=0.05(0,000<0,05)$. Thus, Ha is accepted while Ho is rejected. It means that the independent variables used in this study are simultaneously able to explain the dependent variable well or significantly independent variables significantly influence consumer decisions.

Table 3: Multiple Regression Analysis

Coefficients $^{\mathrm{a}}$

\begin{tabular}{|c|c|c|c|c|c|c|}
\hline \multirow{2}{*}{\multicolumn{2}{|c|}{ Model }} & \multicolumn{2}{|c|}{ Unstandardized Coefficients } & \multirow{2}{*}{$\begin{array}{c}\text { Standardized Coefficients } \\
\text { Beta } \\
\end{array}$} & \multirow[t]{2}{*}{$\mathrm{t}$} & \multirow[t]{2}{*}{ Sig. } \\
\hline & & $\mathrm{B}$ & Std. Error & & & \\
\hline \multirow[t]{8}{*}{1} & (Constant) & 21,733 & 3,310 & & 6,566 &, 000 \\
\hline & Product &, 080 &, 155 &, 065 & 2,516 &, 000 \\
\hline & Price & 165 & ,268 & 071 & 2,618 &, 000 \\
\hline & Place & ,509 &, 198 & 426 & 2,565 &, 000 \\
\hline & Promotion & 677 & ,339 &, 535 & 1,999 &, 000 \\
\hline & People &, 121 & 210 &, 075 & 2,577 &, 000 \\
\hline & Physical Evident & ,304 &, 285 &, 165 & 2,066 &, 000 \\
\hline & Process & , 191 & ,407 & 107 & 2,470 &, 000 \\
\hline
\end{tabular}

a. Dependent Variable: Decision in Continuing

$\hat{Y}=21,733+0,080 X_{1}+0,165 X_{2}+0,509 X^{3}+0,677 X_{4}+0,121 X_{5}$ $+0,304 X_{6}+0,191 X_{7}+e$

From the above regression analysis, the constant of 21.733 indicates that when product, price, place, promotion, person, physical proof, and process are equal to one, then the decision to continue education will increase by 21.733. A positive value coefficient means there is a positive relationship between product, price, place, promotion, person, physical evidence, and process with the decision to continue education.

All variables get $\mathrm{t}$ count $>\mathrm{t}$ table $=1.9966$, with significant value $<\alpha=0.05$. Then, Ha accepted and Ho rejected. It can be concluded that all variables partially give a significant influence on the decision in education $(\mathrm{Y})$.

Table 4: Coefficient of Determination

$$
\text { Model Summaryb }
$$

\begin{tabular}{|c|c|c|c|c|}
\hline Model & $\mathrm{R}$ & R Square & Adjusted R Square & Std. Error of the Estimate \\
\hline 1 &, $607^{\mathrm{a}}$ &, 368 &, 301 & \begin{tabular}{|c|}
2,829 \\
\end{tabular} \\
\hline
\end{tabular}

In the coefficient of determination test $\left(\mathrm{R}^{2}\right)$ where the value of $\mathrm{R}$ square is 0.368 or $36.8 \%$, it shows that the independent variable (service marketing mix) has an influence on the dependent variable (decision on continuing education at SMK Lugina Rancaekek while the rest $63.2 \%$ influenced by other variables not examined in this study $[6,10]$.

\section{Conclusion}

Product have a significant effect on the decision in continuing education at SMK Lugina Rancaekek. And Price have a significant effect on the decision in continuing education at SMK Lugina Rancaekek. It is expected that the school can improve all aspects related to the marketing mix of services consisting of products, prices, places, promotions, people, physical evidence, and processes that will further increase the number of students who attend school at Lugina Rancaekek SMK.

Place have a significant effect on the decision in continuing education at SMK Lugina Rancaekek. Promotion have a significant effect on the decision in continuing education at SMK Lugina Rancaekek. People have a significant effect on the decision in continuing education at SMK Lugina Rancaekek. It is expected that schools need to pay attention to organizational climate factors, related to providing assistance, guidance, and coaching. And it would be better to do special training in connection with the problems of service mix marketing strategy.

Physical Evidence have a significant effect on the decision in continuing education at SMK Lugina Rancaekek. Process have a significant effect on the decision in continuing education at SMK Lugina Rancaekek. It is expected for researchers who will conduct research on the same topic with this research, should use different aspects and methods in order to complement the results of this study and the discussion becomes more profound.

\section{References}

[1] Ministry of Education. 2003. Law Number 20 of 2003 concerning National Education System. Ministry of National Education.

[2] Kotler, P. and Gary, A. 2014. Principle of Marketing. Pearson Prentice Hall.

[3] Kotler, P. and Kevin, L. K. 2016. Marketing Management. Pearson Education.

[4] Abdurrahman, N. H. 2015. Marketing Strategy Management. Faithful Library.

[5] Alma, B. 2014. Marketing Management and Marketing Services. Alfabeta.

[6] Gazali, S. 2017. Analysis of the Influence of Service Marketing Mixes on Student Decisions in Choosing Balikpapan Madani College of Economics. Civil Management Accounting Journal, 1(3).

[7] Lovelock, C. 2012. Marketing Services: Human, Technology, Strategy. Erlangga.

[8] Lupiyoadi, R. 2013. Services Marketing Management. Salemba Empat.

[9] Malhotra, K. N. 2010. Marketing Research. Prentice Hall.

[10] Gusdiandika, R. and Kukuh, S. 2012. Effect of School Promotion on Student Decisions in the Election of SMK Ten November Sidoarjo. Channel, 1(1), 1-10. 